ON A COLLECTION OF SLUGS FRONI TIIE SANDWICH ISLANDS.

By Walter E. Collivge, F.Z.S.,

Assistant Lecturer and Demonstrator in Zoology and Comparative Anatomy, Jason College, Birmingham.

Read 19th January, 1896.

Throvgr the kindness of Mr. E. R. Sykes, I hare been permitted to make an examination of the slugs collected bs Mr. R. C. L. Perkins in the Sandwich Islands for a Joint Committee of the Royal Society and British Association. Some of the material has been hardened in a solution of corrosire sublimate, which has made dissection somewhat difficult. I hare, howerer, been able to make out fairly well the chicf features of the alimentary and reproductire organs.

I am also greatly indebted to Mr. Sykes for the assistance he has rendered me with respect to the bibliography; whilst to Professor Cockerell I must express $m_{r}$ thanks for directing my attention to a species of Janella, said to have come from the Sandrich Islands.

'ihe first mention of the slur-fauna of the Sandwich Islands is that by Eydoux and Souleyet, in their account of the molluscan fauna of this region in 1852-3. They there describe a new species, Limax Sandwichiensis, and figure the animal and shell. Their description is as follows :-

"Limax Sanduichicnsis, nobis, pl. xxriii, figs. 8-11.-Timax, corpore clerato, postice acuminato, obliquè striato, suprì nigricante, subtus albido; clypeo oblongo, anticè angusto, subrugosa. Ossiculo orato, crasso, suprì gibboso."

Semper (1\}) in a foot-note to his description of Limax tennellus, Nilss., says that there is a species-Limax Sandzoichiensis-exceedingly like L. tennellus, but somewhat smaller, which occurs in the Sandwich Isles. In external appcarance and in the form of the reproductire organs, the two are in complete harmony. The only differences he found were some minor ones in the tecth of the lingual ribbon, and to these he was inclined to attach but little importance. Semper seems to hare had but little doubt that the Limax he examined was ilentical with L. tennellus, Nilss. Unfortunately he makes no mention of the shell.

It was pointed out by Tryon (14) that in the figure of the shell of Limax Sandwichiensis, there was a central nucleus, like a Patella. With some rescrre, on account of the insufficient description, he placed this species in the genus Amalia.

Hernemann (7) records from the Sandwich Islands an Agriolimax Sandicichiensis (Soulejet), which he thought to be near Agr. lavis.

Whether the slugs examined by Semper and Heynemann wore the same as those collected by Eydoux and Soulcyet, it is impossible to say. Neither Semper nor Heynemann, one would suppose, could orerlook the very peculiar shell. 
The slug here described as Agriolimax globosus is not unlike that imperfectly characterized by Eydoux and Souleyet in 1852, but it has no specialized shell such as they detail and figure; on the contrars, there were in the three specimens dissected only loose, minute, calcarcous discs. Unless other material be forthcoming, I fear that the Agr. Sandacichiensis, Erd. and Soul., will haro to remain a rery doubtful species, for at present we know of no species of Agriolimax or Amalia that possesses a shell at all approaching the one figured by Eydoux and Souleset, and reproduced by Tryon (14), pl. liv, figs. 71-3. It is quite distinct from any of the known genera of limacidx, and that, I agree with Tryon, is in itself sufficient to justify the constitution of a new genus.

\section{Agrtolinix globosus, n.sp.}

Animal, head, mantle, and dorsum of a bluish-gres colour; sides of the body a light jellowish-brown. Posterior portion of the body attenuated, pointed, and keeled. Mantle large, pointed in front. Foot-sole and foot-fringe sellow. Lateral ruga arranged obliquely. Shell consists of a. series of loose, minute, calcareous discs. Length (in alcohol) $15-18 \mathrm{~mm}$., mantle $5 \cdot 75-7 \mathrm{~mm}$.

IIab.- IIauna Loa, Hawaii.

Anatomy. - There are four conrolutions in the intestine, and the right lobe of the liver forms the apical portion of the visceral mass. The generative organs are rery distinct from those of the other species of the genus, the nearest ally being Agr. tennellus, Nilss. The free oriduct is a long wide tube, and opens into a much conroluted sac-like oriduct. There is no distinction betreen the upper and lower portion of the free oviduct as in L. tennellus, Nilss. The penis is a wide short tube, terminating in a bulbous head, to which the retractor muscle is attached; this muscle, unlike that of $L$. tennelluts, is short and broad. From the side of the penis (Fig. I), the vas deferens passes off, leading into a wide tube, the prostatic portion of the common duct. There is a small bilobed flagellum (Fig. I, $\boldsymbol{A}$.), passing off from the posterior portion of the penis. In $L$. tennellus there is little or no flagellum. The receptaculum seminis is an irregularly shaped sae with a short duct, which opens some little distance behind the penis; in this particular it differs from any other species of the genus, so far as I am aware. The albumen gland is small. The hermaphrodite gland (Fir. I, h.gl.) is single, and opens into the common duct by a short hermaphrodite duct.

\section{Agriolmani Perhissi, n.sp.}

Animal, ground colour light-brown, dorsum, also head and posterior portion of the mantle, darker; sulci black, lighter towards footfringe; foot-sole and foot-fringe yellowish-brown. Mantle long and attenuated. Lateral rugxe arranged obliquely. Shell absent. Length (in alcohol) $18-21 \mathrm{~mm}$.

IIab.-Lanai, 2000 fect.

Anatomy.-The free oviduct is an unusually long and wide tube, showing a series of constrictions, into the first of which the somewhat 


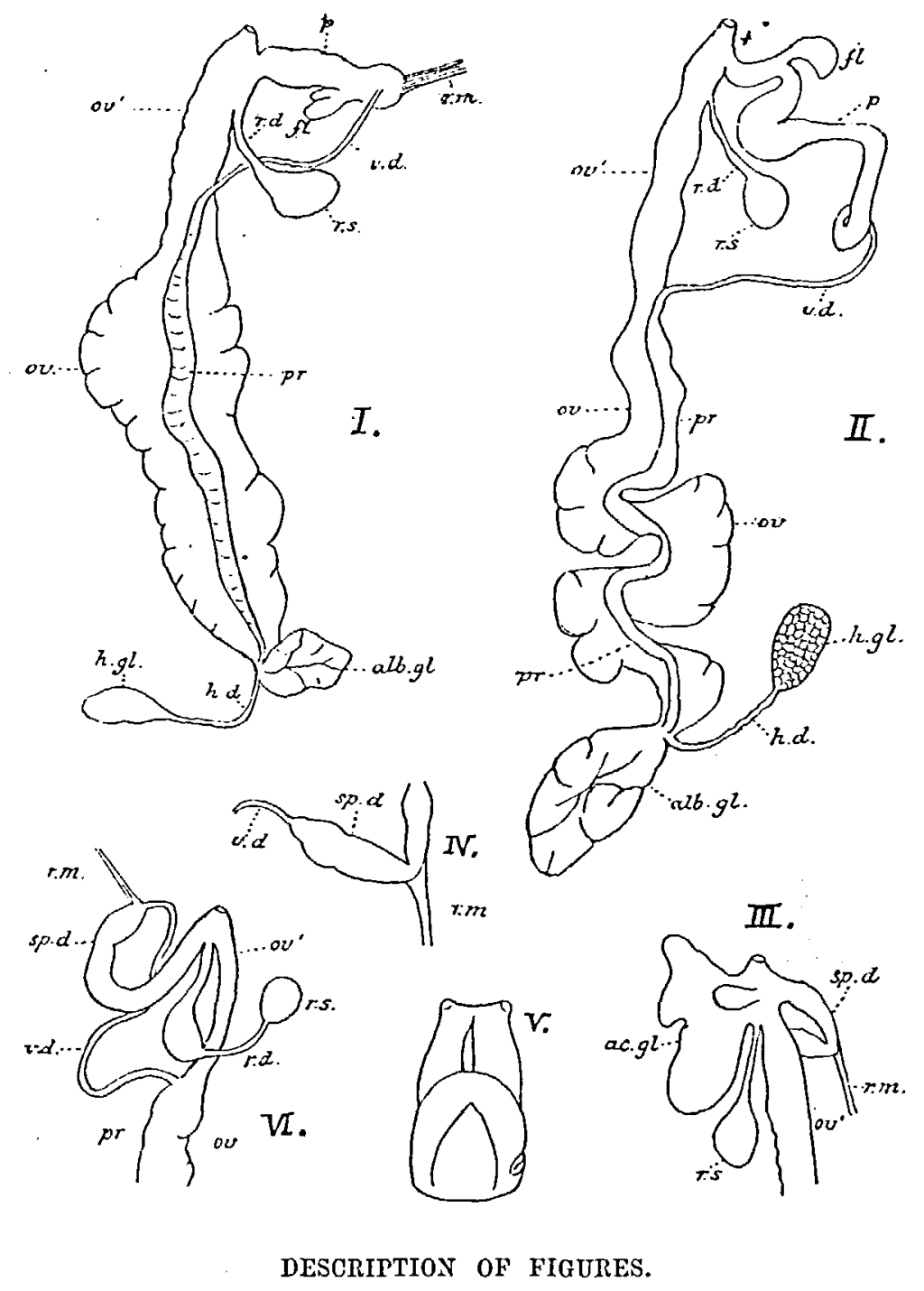

Fig. I. Generative organs of Agriolimax globosus, sp. nor. $\times 3$.

, II. Generative organs of Agriolinax Perkinsi, sp. nor. $\times 8$.

"III. Portion of the generative organs of Amalia gagates, Drap. $\quad \times 8$.

"IT. Sperm-duct of A. gagates, Drap. Enlarged.

"V. Head and mantle of $A$. gagates, Drap.

"VI. Portion of the generative organs of Tebennophorus striatus, Hasselt. $\quad \times 8$. 
Letrentia.

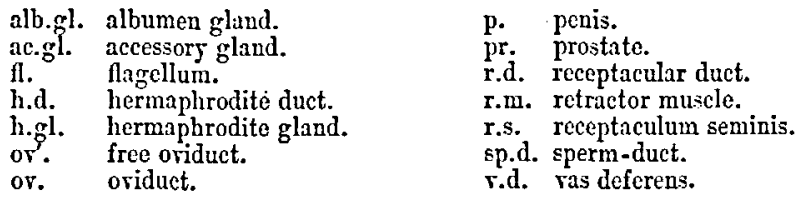

long receptacular duct opens (Fig. II, r.d.). The receptaculum seminis is small and globular. The oviducal portion of the common duct (Fig. II, ov.), is a wide tube folded twice upon itself. The penis is a large twisted organ, and in length considerably exceeds the same organ in any other species of the genus (Fig. II, p.). At a point about one-sixth of its length from the genital opening it rives off a blunt flagellum; it then expands into a sac-like portion, thence it continues for a short distance as a straight tube, and then, making a sharp turn, becomes folded upon itself, at its junction with the ras deferens (Fig. II, v.d.). This latter is a narrower tube, leading into the prostatic portion of the common duct, which is longer and narromer than in $A \%$. globosus. There is a large oval albumen gland. The hermaphrodite gland (Fig. II, $h . g l$.) is somewhat pjriform in shape, and opens into a short conroluted duct.

I hare much pleasure in associating with this interesting species the name of Mr. R. C. L. Perkins.

The differences in the form of the reproductive organs of $A g r$. globosus and $\boldsymbol{A} g r$. Perkinsi are fairly well marked, and easily distinguish them from their nearest allies. The question, however, of how far the form of the penis, free oriduct, etc., vary in a known species, is one of great interest, and must sooner or later be inrestigated. Dr. J. F. Babor, of Prague (2), has published somo interesting notes in connection with this subject, and it is greatly to be hoped that he may find opportunity for further extending his researehes.

The species of Agriolimax, recently described as new by Simroth (12), scem to me to be established on minute rariations common to all mollusca, as do those figured and described by Babor and Kostal (1). Possibly later inrestigations may prore that in this genus the reproductive organs are subject to a wide range of rariation, and that recourse will have to be had to the general anatomy. In $A$. Soucerby $i i$ and $A$. gagates the only rariations in the generative organs I have been able to find are in the form and number of the occessory glands and the constrictions in the sperm-duct (4).

\section{Audurs gatates (Drap.).}

The specimens of $\mathcal{A}$. gagates which come from Mraui differ slightly from those I have examined from rarious European localities. The groore on the mantle terminates anteriorly as a sharp point (Fig. V); and on the head, in the mid-dorsal line, there is the peculiar groove so conspicuous in $A$. robici, Simr. Internally there are also slight differences in the form of the sperm-duct (Figs. III and IV, sp.d.) and accessory glands. Probably all these characters are due to 
isolation, and are not sufficient in themselves to separate them from tho European $A$. gagates.

\section{Tebexwophonus striates (Hasselt).}

There are two examples of this species, which differ somewhat externally, but an cxamination of the generatice system (in part represented in Fig. VI) leares no doubt that they both belong to this species.

IIab.-Mount Tantalus, near Honolulu.

This species was first described by IIasselt (6) under the generic title of Meghimatium. In 1867 Ton Martens (10) placed it in the genus Philomycus, Rafinesque, 1820. The anatomy has been carefully described and figrured by Keferstein (9). I am using Binner's generic title of Tebemnophorus, which, I think, is preferable, secing that it is accompanied by a fairly good diagnosis. While admitting many of Professor Cockerell's arguments (3) anainst the rule, "once a synonym almays a synonym," I think the safer plan is to accept such a rule. Concerning Binney's description there can be no doubt.

\section{Tebexxophorus Australis (Bergh)?}

There is only one example of this species, and the generatice organs are not dereloped. There is a single black line at either side of the boly, and the dorsum is mottled with black. Length (in alcohol) $23 \mathrm{~mm}$.

IHab.-Mount Tantalus, Oahu.

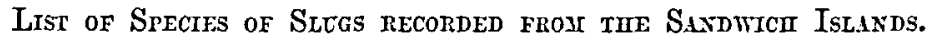

Thoso marked with an asterisk are doubtful.

Limax tennellus, Nilss. Seo Semper (11).

* Agriolimax Sandwichiensis, Sou-

leyet.

Agriolimax globosus, n.sp.

Agriolimax Perkinsi, n.sp.

Amalia gagates, Drap.

* Amalia Sanducichiensis, Eydoux. Tebennophorus strintus, Hrasselt. Tebennophorus Australis (Bergh)? Janella sp.

Dr. J. G. Cooper records a species of Janella, "found in a bale of the Palu fern, brought from the Sandwich Islands for mattrass-making." (Vide Bull. Calif. Acad. Sci. 1871, rol. r, p. 195.)

\section{Brbltography.}

1. Babor, J. and Koštál, J_-“Přispěrky ku poznáni pomérů pohlarnich u nékterch Limacïdủ": Sitz. Gesell. Wiss. Irag. Math. Nat. Classe, 1893, No. li, p. 7, Taf. xx.

2. Babor, J. F._" Über den Cyclus der Geschlcehtsentwicklung der Strlommatophoren": Verh. deutsch. Zool. Gesell. 1894, pp. 55-61, figs. 1-10. 
3. Cockerell, T. D. A.- "A Check-List of the Slugs" : Conchologist, vol. ii, 1893 , p. 215.

4. Collinge, W. E.-"On the Generative Anatomy of Amalia marginata, Drap., and some remarks upon the Genus": Journ. Malac., rol. iii, 1894, pp. 70-3, fig. 1 .

5. Eydoux and Souleyct.- "Voyage autour du monde sur la corrette La Bonite." Paris, 1852: Zoologie, Tom. ii, p. 497.

6. Hasselt, F. C. van.- "Extrait d'une lettre de F. C. ran Hasselt sur les Mollusques de l'île de Jara": Bull. Sci. Nat. Geol., iii, 1824, pp. 81-7.

7. Heynemann, D. F.- "Dio Nackten Landpulmonaten des Erdbodens": Jahrb. Deutsch. Malak. Gescll. 1885, pp. 236-330.

8. "Die Kicfer von Philomycus Carolinensis, Bosc., und Australis, Bergh": Nachr. Deutsch. Malak. Gesell., iii, 1871, pp. 1, 2, Taf. i, figs. 1, 2.

9. Keferstein, W.- " Ueber die Anatomic der Gattungen Incillaria, Benson, und Meghimatium, Hasselt, im Vergleich mit der ron Philomycus, Rafinesque": Malak. Blatt. 1866, pp. 64-70, Taf. i.

10. Martens, E. ron.-Preussische Exped. Ost-Asien: Zool. Theil, Bd. ii, p. 178.

11. Semper, C.- "Reisen im Archipel der Philippinen." Th. II, Bd. iii, Landmollusken (1870), p. 84 , note.

12. Simroth, H. - "Ueber einige ron Herrn Dr. Sturany auf der Balkanhalbinsel erbeutete Nacktschnceken": Ann. k.k. naturhist. Hofmuseums, ix (1894), pp. 391-4, Taf. xix, figs. 1-11.

13. "Versuch ciner Naturgeschichte der Deutschen Nacktschnecken": Zeitsch. Wiss. Zool., xlii (1885), pp. 203-366, pls. rii-xi.

14. Tryon, G. TV.- "M[anual of Conchology." Ser. ii, vol. i, 1885, p. 220, Taf. lir, figs. 70-3. 